\title{
THE UTILIZATION OF GOOGLE CLASSROOM AS E-LEARNING MEDIA OF ENGLISH FOR EFL STUDENTS AT VOCATIONAL HIGH SCHOOL STUDENTS
}

\author{
Cucum Rohmawati; Dede Rohadi Fajri \\ SMK N 3 KOTA SERANG, UNIVERSITAS BANTEN JAYA \\ Serang, Indonesia \\ cucumrohmawatispd@gmail.com, dederohadifajri@unbaja.ac.id
}

\begin{abstract}
Based on the preliminary survey, it is known that SMKN 3 Kota Serang has tried to have e-learning to support online teaching and learning activities, so teachers and students will be able to do online learning in the pandemic of covid-19.A qualitative approach is used in conducting this research because it describes the Utilization of Google Classroom as E-Learning for conducting the English teaching-learning process during pandemic Covid-19. The case study was chosen as the research method in this study. From the result in figure 1, it can be seen that most respondents were enthusiastic during the English teaching-learning process through Google Classroom. Based on the post-survey, most respondents could understand the use of all the main features of Google Classroom, such as creating a new class, subject lesson, assignment, quiz, question, grading assignment and quiz, posting announcement for their students, etc. From all explanations of the utilization of Google Classroom for teaching English in SMKN 3 Kota Serang, it can be seen that a positive result was gotten. It is also supported by the result of a survey about students' perception of English learning through the utilization of Google Classroom. Students' Feedback of Utilization Google Classroom as E-learning Media of English. From the result in figure 1, it can be seen that most respondents were enthusiastic during the English teaching-learning process through Google Classroom.
\end{abstract}

Keyword: Google Classroom, E-Learning, EFL, Vocational.

\section{INTRODUCTION}

Indonesia is still dealing with a pandemic of Severe Acute Respiratory Syndrome Coronavirus 2 (SARS-COV-2) or Covid-19. Covid-19 is a kind of common virus that causes an infection in the nose, sinuses, or upper throat has spread so fast and to almost all countries. World Health Organization (WHO) identified Covid-19 as a new type of coronavirus in early 2020 , after a December 2019 outbreak in Wuhan, China.

This virus spreads very quickly and has spread to almost all countries, including Indonesia, in just a few months. So that, on March 11, 2020 WHO declared this outbreak as a global pandemic. This situation which happened in several countries including Indonesia, forced the 
government of Indonesia to Enforce Restrictions on Community Activities.

Some local governments also decided to implement policies of teaching learning activities, where the process of teaching learning should be implemented by doing online learning.

Stem (2004:4) stated that Online learning is education that takes place over the Internet. It is often referred to as "elearning" among other terms. In doing online learning, the teacher should make sure that teaching earning activity runs well although the teacher and students are in different places. And the teacher also should be able to choose and design suitable media for teaching in order to make students interest to learn so the learning objectives can be achieved.

Online learning can be implemented through personal computer tools or smartphone, and there are many Mobile Assisted Learning applications which provides various application to be selected.

Based on preliminary survey, it is known that SMKN 3 Kota Serang has tried to have e-learning to support online teaching and learning activities, so teachers and students will be able to do online learning in the pandemic of covid-19. But, this effort is difficult for students because they need much internet quota for accessing it. And the result there is many students who don't join the class although they have android smartphone. Then the teachers just share the material and quizzes through Whatsapp and taking pictures. It's so difficult to achieve learning goals.

Then, the teachers of SMKN 3 Kota Serang choose one of the applications that's easy not only for the teachers, but also for students, it is Google Classroom. This application which is called as Classroom (GC) at which the features are streams, classwork, and people (Ferre, 2019). This application is the latest features of the Google App for Education that can be utilized by teachers and students in teaching learning process.

Google Classroom is a learning management system that teachers can construct active learning with studentcentered, collaborative, and unforgettable approach just by means of Google Classroom, because it provides easy-to-use learning features with all students can take part (Iftakhar, 2016, p. 12).

Google Classroom can be applied as a support medium for conventional learning. Google classroom has some features for creating group and sub-group for each class, assignments, quizzes, grading assignments and writing subject materials and tasks, saved automatically in Google Drive (Shaharanee, Jamil and Rodzi, 2016) 
Based on the result of interview with English teachers of SMKN 3 Kota Serang, Google Classroom gives many advantages for the teachers, because it has many features that teachers can use for doing online teaching learning activities. They can create announcement in class or provide online tests. They can also allow students to send assignments immediately with one click without utilizing paper. Then, the teachers can utilize Google classroom for discussion rooms, where the teachers create an explanation of English material and students can't understand it, the students can directly ask the teacher through commenting on the teachers' post, and students can also interact with others. Not only those, the students can also share resources with others by providing answers to questions in stream features, and the teachers can utilize Google classroom to instruct, assign, and discuss with their students online at the same time simultaneously.

The teachers' explanation is in line with Ressler (2017) who stated that Google Classroom was easy to be accessed, because it allowed any personal Google users to join classes without the requirement of having a $G$ Suite for Education account.

The students of SMKN 3 Kota Serang also said that google classroom didn't spend a lot of internet quota, and it can be access through the aid quota provided by the government.

Based on explanation above, the researcher purposes to conduct a research tries to conduct a research about The Utilization of Google Classroom as ELearning Media of English for EFL Students at Vocational High School Students.

\section{METHOD}

Qualitative approach is used in conducting this research, because it describes about the Utilization of Google Classroom as E-Learning for conducting English teaching learning process during pandemic Covid-19. The case study was chosen as the research method in this study, which was conducted at SMKN 3 Kota Serang which was one of state vocational high school in Serang City from August to November 2021. Four English teachers and 3 classes from $10^{\text {th }}, 11^{\text {th }}$, and $12^{\text {th }}$ grade were purposively chosen as participants. The three classes were chosen as the respondents based on their activities in English teaching learning process during Pandemic Covid-19 era. Creswell (2008) stated that qualitative research is a process of scientific research that is intended to understand human problems in a social context by creating a comprehensive and 
complex picture presented, reporting detailed views of sources of information, and carried out in natural settings without any intervention from researchers. Meanwhile, Gustafsson (2017) stated that a case study can be defined as an intensive study about a person, a group of people or a unit, which is aimed to generalize over several units.

In doing this research, literature study, observation and interview with the teachers of SMKN 3 Kota Serang and also students are carried out to obtain the necessary data. Then, the data are reduced, displayed, and verified or concluded. Member checking was done by taking the conclusion or information back to the participants so that they could determine the accuracy of the conclusion.

\section{DISCUSSION}

Preliminary survey was conducted before research started. Based on the preliminary survey result, four teachers are familiar with the use of technology. Most of them already knew about Google Classroom but $50 \%$ of them have used it.

This study examined that google classroom as E-Learning Media of English for EFL Students at Vocational High School Students is effective enough to be conducted in SMKN 3 Kota Serang.
There are some reasons why Google Classroom stated as effective media for doing online learning especially in teaching and learning English?

The first, the series of product and program has been developed by google for education's need. There are many services of Google for education, that is Google Workspace for Education which consist of many productive applications includes Docs, Gmail, Calendar, Drive, Meet. Those applications are integrated with Google Classroom, so it's assumed that Google Classroom will help teaching learning process runs effectively.

The second, there are four English skills that students should be able which consist of reading, writing, listening and speaking, Google Classroom can serve it all. The teacher can give explanation by posting materials or announcements through writing in stream menu. It can engage students in question-driven discussions, where the students can ask the teacher if they find difficulties by adding class comments. The teacher can directly answer students' question

The third, the students should be mastered in speaking. Through Google Classroom, the teacher can integrate it with Google Meet and start meeting. The students can join meeting by generating link through google classroom, and it's can 
be done for implementing speaking class, where the teacher can ask students something and stimulate them to speak and students will try to speak, so there will be interactions.

The forth, for listening, the teacher can add a video in stream menu or a link of YouTube related to the base competence and the material that should be achieved by students at that time. By suing video, the teacher can invite students to watch and after that write the conclusion of video given. It will treat students to listen carefully to know about what the message of video given.

The fifth is writing. In vocational high school, there are some materials about text, so in teaching writing, the teacher can show one example of texts with the explanation of generic structure and language features. Then, they can invite and stimulate students to do the same thing through Google Classroom and submit it in the classwork.

The sixth, when the teachers want to conduct evaluation know about students' understanding related the topic and material given, they can conduct evaluations through streams menu. The students can track classwork and submit assignments there, and the teachers can check originality, feedback, and students' grades, because it will automatically show students' grade whole the class. The teacher also can limit the tie of evaluation and invite parents and guardians to sign up for email summaries with a student's upcoming or missing work. So, the teacher could provide the students' feedback in the form of suggestion, appreciation, or encouragement to the students to be more enthusiastic in learning.

From all explanation of the utilization of Google Classroom for teaching English in SMKN 3 Kota Serang, it can be seen that the positive result was gotten. It is also supported by the result of survey about students' perception in English learning through the utilization of Google Classroom. The participants who consist of $10^{\text {th }}, 11^{\text {th }}$, and $12^{\text {th }}$ grade which consist of 36 students for each class stated that the Google Classroom provided benefits for both personally and to the school (shown in Figure-1).

IN YOUR OPINION, DOES GOOGLE CLASSROOM GIVE BENEFITS FOR YOU

IN LEARNING ENGLISH? 118 Respondents

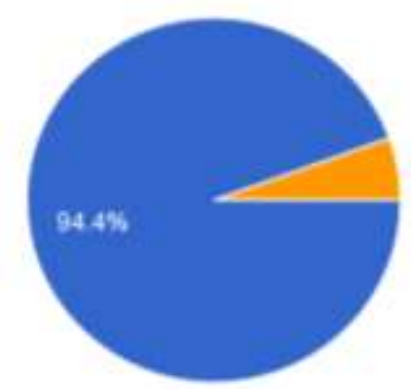


Figure 1. Students' Feedback of Utilization Google Classroom as E-learning Media of English

From the result in figure 1, it can be seen that most respondents were enthusiastic during English teaching learning process through Google

Classroom. Based on the post survey, most respondents could understand the use of all the main features of Google Classroom, such as creating new class, subject lesson, assignment, quiz, question, grading assignment and quiz, posting announcement for their students, etc.

\section{CONCLUSION}

It summarizes to your new findings based on the research. It may state the strengths and weaknesses of your methodology. It may also specify the room for future improvement.

Indonesia is still dealing with a pandemic of Severe Acute Respiratory Syndrome Coronavirus 2 (SARS-COV-2) or Covid-19. This virus spreads very quickly and has spread to almost all countries, including Indonesia, in just a few months. This situation which happened in several countries including Indonesia, forced the government of Indonesia to Enforce Restrictions on Community
Activities. Some local governments also decided to implement policies of teaching learning activities, where the process of teaching learning should be implemented by doing online learning. Stem (2004:4) stated that Online learning is education that takes place over the Internet. And the teacher also should be able to choose and design suitable media for teaching in order to make students interest to learn so the learning objectives can be achieved. Online learning can be implemented through personal computer tools or smartphone, and there are many Mobile Assisted Learning applications which provides various application to be selected. And the result there are many students who don' join the class although they have android smartphone. Then the teachers just share the material and quizzes through Whatsapp and taking pictures. Then, the teachers of SMKN 3 Kota Serang choose one of the applications that are easy not only for the teachers, but also for students, it is Google Classroom. This application is the latest features of the Google App for Education that can be utilized by teachers and students in teaching learning process. Google Classroom is a learning management system that teachers can construct active learning with student-centered, collaborative, and unforgettable approach just by means of Google Classroom, 
because it provides easy-to-use learning features with all students can take part (Iftakhar, 2016, p. Google Classroom can be applied as a support medium for conventional learning. Based on the result of interview with English teachers of SMKN 3 Kota Serang, Google Classroom gives many advantages for the teachers, because it has many features that teachers can use for doing online teaching learning activities. Preliminary survey was conducted before research started. Based on the preliminary survey result, four teachers are familiar with the use of technology. The first, the series of product and program has been developed by Google for education's need. The second, there are four English skills that students should be able which consist of reading, writing, listening and speaking, Google Classroom can serve it all. The teacher can give explanation by posting materials or announcements through writing in stream menu. The third, the students should be mastered in speaking. Through Google Classroom, the teacher can integrate it with Google Meet and start meeting. The forth, for listening, the teacher can add a video in stream menu or a link of YouTube related to the base competence and the material that should be achieved by students at that time. The fifth is writing. The students can track classwork and submit assignments there, and the teachers can check originality, feedback, and students' grades, because it will automatically show students' grade whole the class. The teacher also can limit the tie of evaluation and invite parents and guardians to sign up for email summaries with a student's upcoming or missing work. From all explanation of the utilization of Google Classroom for teaching English in SMKN 3 Kota Serang, it can be seen that the positive result was gotten. It is also supported by the result of survey about students' perception in English learning through the utilization of Google Classroom. Students' Feedback of Utilization Google Classroom as E-learning Media of English. From the result in figure 1 , it can be seen that most respondents were enthusiastic during English teaching learning process through Google Classroom.

\section{REFERENCES}

Cresswell, John W. (2008). Educational Research: Planning, Conducting and Evaluating Quantitative and Qualitative Research, 3rd ed. New Jersey: Pearson Merril Prentice-Hall.

Ferre, M. [Pocketful of Primary]. (2019, July 7). Getting started with google classroom| EDTEACH made easy google classroom tutorial [video file]. Retrieved from https://youtu.be/rCNImsWUxZA

Gustafsson J. (2017). Single case studies vs multiple case studies: a comparative 
study. (Thesis). Sweden: Halmstad University

Iftakhar, S. (2016). Google classroom: what works and how? Journal of Education and Social Sciences, 3, 12. Available at https://www.jesoc.com/wpcontent/uplo ads/2016/03/KC3_35.pdf

Ressler, Gene. (2017). Google Classroom: Now open to even more learners. Retrieved January $\quad 11,2020$ from

https://web.archive.org/web/202003301 10814/https://blog.google/topics/educat ion/google-classroom-now-open-evenmore-learners

Shaharanee, I.N.M., Jamil, J.M., \& Rodzi, S.S.M. (2016). The application of Google Classroom as a tool for teaching and learning. Journal of Telecommunication, Electronic and Computer Engineering, 8(10).

Stem, Joshua. (2018). Introduction to Online Teaching and Learning. Retrieved January 5, 2020 from https://nanopdf.com/download/joshuastern-phd-west-los-angeles-college_pd 